Assembly Language Assembled for the Sinclair ZX81 


\section{Macmillan Computing Books}

Assembly Language Programming for the BBC Microcomputer Ian Birnbaum

Advanced Programming for the 16K ZX81 Mike Costello

Microprocessors and Microcomputers - their use and programming Eric Huggins

The Alien, Numbereater, and Other Programs for Personal Computers with notes on how they were written John Race

Beginning BASIC Peter Gosling

Continuing BASIC Peter Gosling

Program Your Microcomputer in BASIC Peter Gosling

Practical BASIC Programming Peter Gosling

The Sinclair ZX 81 - Programming for Real Applications

Randle Hurley

More Real Applications for the Spectrum and ZX81 Randle Hurley

Assembly Language Assembled - for the Sinclair ZX81 Tony Woods

Digital Techniques Noel Morris

Microprocessor and Microcomputer Technology Noel Morris

Understanding Microprocessors B. S. Walker

Codes for Computers and Microprocessors P. Gosling and

Q. Laarhoven

Z80 Assembly Language Programming for Students Roger Hutty 


\title{
Assembly Language Assembled for the Sinclair ZX81
}

\author{
Anthony Woods
}

Lecturer in Computer Science

Peterborough Technical College

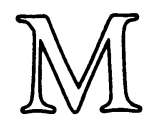


(C) Anthony Woods 1982

All rights reserved. No part of this publication may be reproduced or transmitted, in any form or by any means, without permission.

First published 1983 by

THE MACMILLAN PRESS LTD

London and Basingstoke

Companies and representatives

throughout the world

The paperback edition of the book is sold subject to the condition that it shall not, by way of trade or otherwise, be lent, resold, hired out, or otherwise circulated without the publisher's prior consent in any form of binding or cover other than that in which it is published and without a similar condition including this condition being imposed on the subsequent purchaser. 


\section{Contents}

Preface ix

1 INSIDE THE COMPUTER 1

1.1 Microcomputers 1

1.2 The Z80 Central Processing Unit 2

1.3 Memory 3

1.4 Instructions 4

1.5 Assembly Language 5

2 ASSEMBLY LANGUAGE PROGRAMS

2.1 Assembling Programs

2.2 The ZXAS Program 1

$\begin{array}{lll}2.3 & \text { Using ZXAS } & 10\end{array}$

2.4 The ZXDB Program 11

$\begin{array}{lll}2.5 & \text { ZXDB Commands } & 12\end{array}$

$\begin{array}{ll}2.6 & \text { Single Stepping } \\ 2.7 & 15\end{array}$

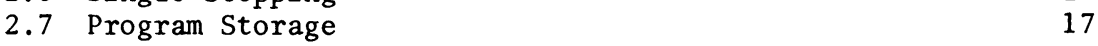

3 SOME SIMPLE INSTRUCTIONS 19

$\begin{array}{ll}3.1 \text { The Basic Operations } & 19\end{array}$

$\begin{array}{ll}3.2 & \text { Loading a Register } \\ 3.3 & 19\end{array}$

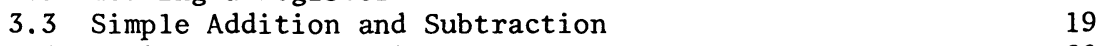

$\begin{array}{ll}3.4 & \text { Moving Between Registers } \\ 3.5 & 20\end{array}$

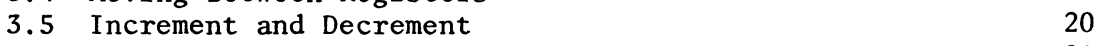

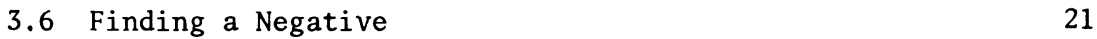

3.7 Addressing Modes - Immediate and Extended 21

3.8 An Example Program 22

3.9 Program 23

4 SUBROUTINES AND OUTPUT TO THE SCREEN 25

$\begin{array}{lll}4.1 & \text { Subroutines } & 25\end{array}$

4.2 The CALL and RET Instructions 26

$\begin{array}{ll}4.3 & \text { Another Subroutine Instruction }\end{array}$

4.4 Some Useful Subroutines 28

$\begin{array}{lll}4.5 & \text { Labels } & 29\end{array}$

$\begin{array}{ll}4.6 \text { Program } & 29\end{array}$

5 UNCONDITIONAL JUMPS AND KEYBOARD INPUT 30

5.1 Unconditional Jumps 30

5.2 Keyboard Input 31

5.3 Character Codes and Values 32

$\begin{array}{lll}5.4 & \text { Program } & 34\end{array}$ 
6 CONDITIONAL JUMPS AND COMPARISONS 35

6.1 The Flag Register 35

6.2 Conditional Jump Instructions 36

6.3 The Compare Instruction 38

6.4 Conditional Loop Termination 39

$\begin{array}{ll}6.5 \text { Program } & 40\end{array}$

7 COUNTING LOOPS 41

7.1 Counting Loops 41

7.2 Number Input 44

$\begin{array}{lll}7.3 & \text { Stacks } & 45\end{array}$

$\begin{array}{lll}7.4 & \text { Stack Instructions } & 46\end{array}$

$\begin{array}{ll}7.5 & \text { Saving and Restoring Registers }\end{array}$

$\begin{array}{lll}7.6 & \text { Program } & 48\end{array}$

8 LOOPS WITHIN LOOPS 49

8.1 Nested Loops 49

8.2 More Addressing Modes $\quad 50$

8.3 Text Output 53

8.4 The Display File 54

8.5 The Subroutine Mechanism 56

$\begin{array}{lll}8.6 & \text { Program } & 57\end{array}$

9 CARRY AND OVERFLOW $\quad 58$

9.1 Arithmetic Conditions 58

9.2 Carry 58

9.3 The Carry Flag $\quad 59$

9.4 Overflow 60

9.5 The Overflow Flag 60

9.6 Conditional Calls and Returns 61

$\begin{array}{lll}9.7 & \text { Program } & 62\end{array}$

10 MULTIPLICATION AND DIVISION 63

10.1 Shifts 63

10.2 The SRL Instruction 63

$\begin{array}{lll}10.3 & \text { The SRA Instruction } & 64\end{array}$

$\begin{array}{lll}10.4 & \text { The SLA Instruction } & 65\end{array}$

10.5 Eight-bit Multiplication and Division 65

$\begin{array}{lll}10.6 & \text { Program } & 67\end{array}$

11 THE LOGICAL BITS $\quad 68$

$\begin{array}{lll}11.1 & \text { Bit Instructions } & 68\end{array}$

11.2 The Bit Test Instruction 68

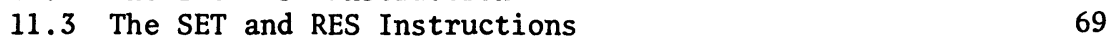

11.4 The Index Registers $\quad 69$

$\begin{array}{lll}11.5 & \text { Logic Operators } & 70\end{array}$

$\begin{array}{lll}11.6 & \text { Logical Instructions } & 71\end{array}$

11.7 Program $\quad 72$

12 ROTATE INSTRUCTIONS AND PARITY

12.1 Rotate Instructions $\quad 74$

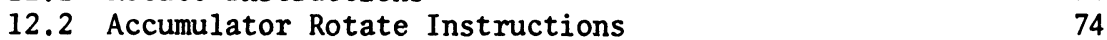

12.3 Register and Memory Byte Rotations 76

12.4 Packing and Unpacking 76

$\begin{array}{lll}12.5 & \text { Parity } & 77\end{array}$ 
13 MULTIPLE BYTE ARITHMETIC $\quad 80$

$\begin{array}{ll}13.1 \text { Why Multiple Byte } & 80\end{array}$

13.2 The Sixteen-bit Arithmetic Instructions 80

$\begin{array}{lll}13.3 & \text { Extended Loops } & 82\end{array}$

$\begin{array}{ll}13.4 & \text { Multiple Byte Arithmetic } \\ 13.5\end{array}$

$\begin{array}{ll}13.5 & \text { Program }\end{array}$

14 BLOCK TRANSFER AND SEARCH $\quad 87$

$\begin{array}{lll}14.1 & \text { Block Instructions } & 87\end{array}$

$\begin{array}{lll}14.2 & \text { Block Transfer } & 87\end{array}$

14.3 Block Search Instructions 9

$\begin{array}{ll}14.4 & \text { Program }\end{array}$

15 DECIMAL ARITHMETIC 93

$\begin{array}{ll}15.1 & \text { Binary Coded Decimal } \\ 15.2 & 93\end{array}$

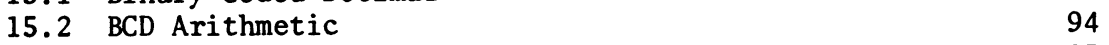

15.3 The DAA Instruction 95

15.4 The Digit Rotate Instructions 96

$\begin{array}{lll}15.5 & \text { Program } & 98\end{array}$

$\begin{array}{lll}16 & 100\end{array}$

$\begin{array}{lll}16.1 & \text { Other Instructions } & 100\end{array}$

$\begin{array}{ll}16.2 \text { The Auxiliary Registers } & 100\end{array}$

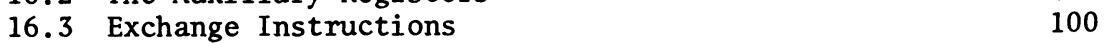

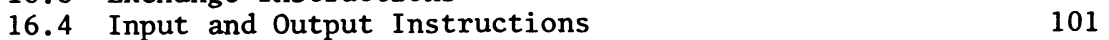

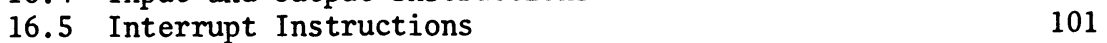

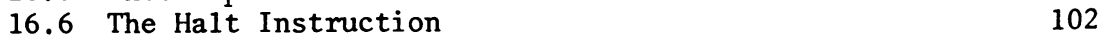

$\begin{array}{lll}\text { Appendix A NUMBER SYSTEMS } & 103\end{array}$

A.1 Other Number Systems 103

A.2 Binary and Hexadecimal Numbers 103

A.3 Binary-hexadecimal Conversion 104

A.4 Decimal to Binary Conversion 105

A.5 Binary to Decimal Conversion 106

A.6 Decimal-hexadecimal Conversion 106

A.7 Binary and Hexadecimal Arithmetic 107

$\begin{array}{lll}\text { A. } 8 \text { Bytes } & 107\end{array}$

A.9 Signed Numbers 108

$\begin{array}{lll}\text { Appendix B HAND ASSEMBLY } & 111\end{array}$

B. 1 General Method 111

B. 2 Numbers and Addresses 111

B. 3 Jump Instructions 113

B.4 Bit Instructions 114

B.5 Index Register Instructions 114

Appendix C HEXADECIMAL-DECIMAL CONVERSION TABLES 116

$\begin{array}{lll}\text { Appendix D } & \text { CHARACTER CODES } & 118\end{array}$ 


$\begin{array}{lll}\text { Appendix } & \text { E } & \text { SUMMARY OF Z80 INSTRUCTIONS } \\ \text { E.1 } & \text { Summary of Flag Operations } & 119 \\ \text { E.2 } & \text { 8-bit Load Group } & 120 \\ \text { E.3 } & \text { 16-bit Load Group } & 121 \\ \text { E.4 } & \text { Exchange Group and Block Transfer and } & 122 \\ & \text { Search Group } & 123 \\ \text { E.5 } & \text { 8-bit Arithmetic and Logical Group } & 124 \\ \text { E.6 } & \text { General Purpose Arithmetic and CPU } & 125 \\ & \text { Control Groups } & 126 \\ \text { E.7 } & \text { 16-bit Arithmetic Group } & 127 \\ \text { E.8 } & \text { Rotate and Shift Group } & 128 \\ \text { E.10 } & \text { Jit Set, Reset and Test Group } & 129 \\ \text { E.11 } & \text { Cal1 and Return Group } & 130 \\ \text { E.12 } & \text { Input and Output Group } & 131 \\ & & 132 \\ \text { F } & \text { SAMPLE PROGRAMS } & 132 \\ \text { F.1 } & \text { The Programs } & 132 \\ \text { F.2 } & \text { Life } & 138 \\ \text { F.3 } & \text { Mailing List } & 144 \\ \text { ANSWERS TO EXERCISES } & \end{array}$




\section{Preface}

This book is for $\mathrm{ZX81}$ users who feel competent at writing programs in BASIC but now want to take their $\mathrm{ZX81}$, and themselves, further.

Assembly language programming takes you into the heart, or should we say brain, of the ZX81 and lets you program it in much finer detail than is possible with BASIC.

The usual reason for writing programs in assembly language is to gain increased processing speed either to give better moving graphics or faster processing of calculations that are repeated often.

Assembly language programming is also used to enable a better program to fit into a small area of memory. All readers will be aware of the limitations of the ZX81 when used with $1 \mathrm{~K}$ of memory and programmed in BASIC. As you will see later, $1 \mathrm{~K}$ of memory means that the computer has approximately 1000 places in its memory, which can be used to store data.

If you write a BASIC program, approximately 30 lines of program will fill this memory. If the program is written in assembly language and then translated into machine code, 30 lines of program will only fill about forty or fifty of the places in memory. However, to be truly comparable an assembly language program which is equivalent to the 30 -line BASIC program, will probably need to be 100 or 150 lines long. This will still only use something like 200 places in memory, leaving enough memory for a display which fills all of the screen.

Until you have written and run some assembly language programs, it is difficult to appreciate the increase in speed which it will give. As a rough guide an assembly language program will run at least twenty times faster than the equivalent BASIC program.

The main problem with programs in assembly language is that you are working directly with the microprocessor of the computer and you are not protected from it, or it from you, as you are when you write BASIC programs. This means that if you make an error in your program, and everyone does, then instead of stopping and waiting for your correction, the computer is likely to go off on its own and it will try to run anything that is in the memory, as though it was a program. This is a computer 'crash' and the only way of regaining control of the $Z \times 81$ is to switch off the machine and start again. 
Before an assembly language can be run on a computer it must be translated into the language used by the computer. This is known as machine code language and consists of a series of numbers; all programs that run on the computer, even BASIC programs, are translated into this form before they are run. The translation from assembly language to machine code language can be performed manually or it can be performed by the computer using a program called an assembler. The assembler program used and described in this book is called ZXAS and I consider it to be the best assembler available for the Sinclair ZX81.

Because machine code language does not have any facilities for finding program errors, finding and correcting errors can be a long and difficult task. Many of the problems involved in correcting a machine code program can be eased by using another computer program which enables you to see what is happening inside the computer while your program is running. The ZXDB program has been used in producing this book and it carries out this function admirably.

Remember that assembly language is just another programming language, like BASIC. You will find that it is no more difficult to learn than BASIC, and possibly easier.

After the first two chapters, each chapter consists of a series of short sections. Each section introduces a new idea and usually includes an exercide on the idea. The exercises are meant to be challenging and they encourage readers to make many discoveries for themselves. Some of the exercise answers include notes on the answers, to extend the reader's understanding.

At the end of each chapter the reader is asked to write a program; the program should be coded, run and tested before starting the next chapter. Each program is designed, as far as possible, to include the ideas introduced in the chapter.

A11 exercises should be done when they are encountered, before continuing with the text. The whole text is designed on the premise that the best way to learn a programming language is by plenty of practical experience. Proficiency in programming is only achieved by programming.

Finally I would like to express my thanks to my wife, Marilyn, for typing the text and her support during the preparation of the book. Thanks are due too to Stephen for acting as a guinea pig and working through the text; by his efforts he has helped to remove the worst of the errors in the text.

Anthony Woods 